\title{
МОДЕЛЮВАННЯ СПОЖИВАЦЬКОЇ ПОВЕДІНКИ В КОНТЕКСТІ ФОРМУВАННЯ ЛОЯЛЬНОСТІ ЦІЛЬОВОї АУДИТОРї̈
}

\author{
SIMULATION OF CONSUMER BEHAVIOR \\ IN THE CONTEXT OF FORMULATION \\ OF LOYALTY OF TARGET AUDIENCE
}

\author{
Степаненко Наталія Іванівна \\ кандидат економічних наук, доцент, \\ Поліський національний університет \\ ORCID: https://orcid.org/0000-0002-0034-9371
}

Волкова Інна Михайлівна

кандидат економічних наук, доцент, Поліський національний університет

ORCID: https://orcid.org/0000-0001-6240-4703

\author{
Stepanenko Nataliia, Volkova Inna \\ Polissia National University
}

\begin{abstract}
Висококонкурений статус сучасних вітчизняних та міжнародних ринків товарів та послуг об'єктивно зумовлює необхідність розробки та обґрунтування нових підходів до формування лояльності цільових споживачів. За умов використання суб'єктами господарювання сукупності актуальних маркетингових інструментів споживацька поведінка нині представляється системоутворюючим чинником формування та реалізації стратегії їх розвитку. Окремою теоретико-методологічною та практичною проблемою вбачається обґрунтування сутності понятійно-категоріального апарату як фрундаментальної основи розробки теорії управління купівельною поведінкою в контексті формування лояльності цільової аудиторії. 3 метою формування стратегічно орієнтованих комунікацій із споживачами непересічного значення набуває обґрунтування моделі споживацької поведінки, що дасть змогу на основі системного підходу забезпечити імплементацію маркетингових систем управління підприємством, орієнтованих на підтримку лояльності споживачів і підвищення есрективності діяльності підприємства. Представлено сучасні підходи до моделювання споживчої поведінки, а також сукупність чинників, що ії детермінують. Акцентовано увагу на теоретичних та емпіричних відмінностях клієнтоорієнтованого та традиційного маркетингу. Встановлено, що інструментарій забезпечення лояльності споживачів концептуально доцільно розробляти на основі максимізації споживчої цінності товарів. Представлено класифікацію споживацької поведінки на ринку в розрізі основних її типів. Визначено закономірності імплементації алгоритму споживацької поведінки та їх застосування у маркетингових технологіях підприємства. Обґрунтовано структурну модель управління споживацькою поведінкою клієнтоорієнтованої компанії.
\end{abstract}

Ключові слова: ринок, управління, маркетинг, поведінка споживача, відносини, стратегія.

Высококонкурентный статус современных отечественных и международных рынков товаров и услуг объективно обуславливает необходимость разработки и обоснования новых подходов к фрормированию лояльности целевых потребителей. В условиях использования субъектами предпринимательской деятельности совокупности актуальных маркетинговых инструментов потребительское поведение ныне представляется системообразующим фактором формирования и реализации стратегии их развития. Отдельной теоретикометодологической и практической проблемой является обоснование понятийно-категориального аппарата как фундаментальной основы разработки теории управления покупательским поведением в контексте фрормирования лояльности целевой аудитории. С целью формирования стратегически ориентированных коммуникаций с потребителями особое значение приобретает обоснование модели потребительского поведения, что даст возможность на основании системного подхода обеспечить имплементацию маркетинговых систем управления предприятием, ориентированных на поддержку лояльности потребителей и повышения эффективности деятельности предприятия. Представлены современные подходы к моделированию потребительского поведения, а также совокупность фракторов, которые его детерминируют. Акцентировано внимание на 
теоретических и эмпирических отличиях клиентоориентированного и традиционного маркетинга. Установлено, что инструментарий обеспечения лояльности потребителей концептуально целесообразно разрабатывать на основании максимизации потребительской ценности товаров. Представлена классисикация потребительского поведения на рынке в разрезе основных её типов. Определены закономерности имплементации алгоритма потребительского поведения и их использование в маркетинговых технологиях предприятия. Обоснована структурная модель управления потребительским поведением клиентоориентированной компании.

Ключевые слова: рынок, управление, маркетинг, поведение потребителя, отношения, стратегия.

With the intensification of competition and the emergence of many brands of similar products on the market, there is a need to form and maintain customer loyalty. Emphasis is placed on the theoretical and empirical differences between customer-oriented and traditional marketing. Commitment presupposes loyalty, while loyalty can exist without psychological attachment to the enterprise. When put into practical conditions, marketers often combine these concepts when considering emotional loyalty (namely commitment) and rational (behavioral) loyalty. It is the formation and maintenance of emotional loyalty (commitment) is of considerable interest to enterprises. However, in modern conditions, most companies do not have experience in establishing partnerships with their customers. The main difficulties for them are the lack of a systematic approach to customer loyalty management and the imperfection of knowledge on the formation of marketing management systems, focused on retaining consumers and increasing their loyalty. The systematic approach to defining socio-economic and behavioral-cultural aspects of consumption as a phenomenon is the methodological basis of the study. Modern approaches to modeling consumer behavior are presented, as well as a set of factors that determine it. It is emphasized that customer-oriented marketing is fundamentally different from the traditional in a number of strategic aspects, due to its primary focus on consumers as specific individuals. Customer-oriented marketing involves a change in the organizational structure of marketing management, approaches to strategic planning and methodological tools of marketing activities of enterprises. It is established that the tools for ensuring consumer loyalty are conceptually appropriate to develop on the basis of maximizing the consumer value of goods. The classification of consumer behavior in the market in terms of its main types is presented. The regularities of implementation of the algorithm of consumer behavior and their application in marketing technologies of the enterprise are determined. The structural model of consumer behavior management of a customer-oriented company is substantiated.

Keywords: marketing, consumer behavior, market, management, relations, strategy.

Постановка проблеми. Актуальність проблематики фрормування лояльності цільової аудиторії як системоутворюючого чинника забезпечення конкурентоспроможності на рівні стратегічних бізнес-одиниць зумовлює необхідність методологічного обґрунтування процесу моделювання споживацької поведінки. Модиорікація товарних ринків, системна зміна структури потреб В2В та В2С споживачів, динамічний розвиток транспортної та інфрормаційної логістики спонукають до пошуку релевантних маркетингових інструментів забезпечення результативності управління купівельною поведінкою споживачів. Окремою методологічною та прикладною проблематикою вбачається розробка моделей споживацької поведінки в розрізі різних груп споживачів 3 огляду на специорічний структурний профріль цільових аудиторій, а також різний масштаб, профріль діяльності та індивідуальну орієнтацію на товарні пропозиції. В цьому контексті нагальною сферою професійного інтересу маркетологів представляється дослідження механізмів прийняття рішення про купівлю, зважаючи на багатофракторність процесу усвідомлення спонукальних мотивів придбання товару. Непересічного значення для управління купівельною поведінкою різних цільових аудиторій набуває обґрунтування мотиваційної, комерційної та процесної складових процесу реалізації купівлі. Такий підхід створює основу для забезпечення клієнтоорієнтованості бізнесу як стратегічного рішення підприємства щодо конфрігурації матеріальних та нематеріальних ресурсів з метою максимізації прибутку на основі задоволення потреб цільових споживачів. В цілому механізм клієнтоорієнтованості передбачає пропозицію споживачам більшої цінності, ніж конкуренти, при цьому цінність як ключовий параметр товарної пропозиції розглядається як різниця між вартістю (корисністю), що споживач набуває в результаті придбання товару і тими ресурсами, що споживач передає виробнику (продавцю) в процесі обміну (гроші, час тощо).

Аналіз останніх досліджень і публікацій. Теоретико-методологічні та прикладні дослідження поведінки споживачів детермінуються розвитком широкого спектру теорій та концепцій суспільного розвитку. Теоретичне обґрунтування місця і ролі споживацьких практик щодо відтворення системи суспільних відносин відображають праці П. Бурд'є, М. Вебера, Т. Веблена, В. Вонг, Д. Говард, В. Зомбарта, Ф. Котлера, Р. Ньюмана, М. Фербера, 
П. Холанда [5]. Обґрунтуванню психологічного аспекту споживацької поведінки присвячено роботи В. Паккарда, що базуються на теорії 3. Фройда та Е. Діхтера. Характерні особливості купівельної поведінки за різного ступеня лояльності споживачів ідентисріковано Г. Асселем. Варто відмітити сучасне процесне тлумачення споживацької поведінки, запропоноване та обґрунтоване Д. Енджелом, Р. Блекуеллом та П. Мініардом, що також здійснили періодизацію генезису теорії споживацької поведінки з огляду на чинники глобальних змін системи економіки та менеджменту [1]. Сучасні дослідження особливостей механізму споживацької поведінки представлено у працях вітчизняних та зарубіжних вчених, зокрема, Г. Багієва, І. Дубровіна, Т. Жовковської, О. Зозульова, Р. Іванової, С. Ілляшенка, Я. Матковської, М. Окландера, О. Посипанової, О. Прокопенко, О. Раца, Д. Семенди, М. Троян, Т. Царьової, О. Шафралюка та ін. [2; 3; 4; 6; 7; 8; 9].

Постановка завдання. Метою дослідження $€$ вивчення теоретико-методологічних й прикладних підходів до обґрунтування поведінки споживачів та визначення детермінант споживацької поведінки в контексті формування лояльності цільової аудиторії на корпоративному рівні та рівні бізнес-одиниць.

Дослідження ґрунтується на сукупності загальнонаукових і спеціальних методів пізнання теоретико-методологічних і концептуальних основ поведінки споживачів. Проведені дослідження щодо існуючих теоретичних підходів і базових положень концепції споживацької поведінки з використанням методів діалектичного пізнання, узагальнення та наукової абстракції дозволили уточнити зміст поняття «лояльність споживачів», під яким слід розуміти процес раціонального споживання та виробництва у суспільстві, що заснований на використанні системного підходу та здійсненні структурної перебудови і структурних зрушень в економіці країни, які відбуваються відповідно до потреб розвитку промисловості, соціальної сорери, людського потенціалу в контексті зниження антропогенного впливу на навколишнє середовище.

Теоретико-методологічним підґрунтям дослідження $є$ концептуальні розробки вітчизняних та іноземних учених, викладені в контексті соціологічних, психологічних та культурних аспектів поведінки споживачів. Представлене дослідження здійснено з використанням теоретико-методологічного обґрунтування сутності френомена лояльності споживачів щодо продуктових та корпоративних брендів, сис- темний підхід в дослідженні механізму фрормування лояльності цільової аудиторії; ситуаційний аналіз детермінант едективності реалізації програм лояльності.

3 метою реалізації завдання дослідження імплементовано загальнотеоретичні, а також методи структурного та теоретичного аналізу, що дало змогу уточнити визначення сутності ключових категорій теорій споживання та споживацької поведінки в контексті тлумачення поведінки споживачів як комунікативної дії.

Виклад основного матеріалу дослідження. Актуальною особливістю сучасних вітчизняних та міжнародних ринків В2С та В2В $€$ турбулентність зовнішнього маркетингового середовища, характерними ознаками якої $€$ непрогнозованість його змін з огляду на вплив форс-мажорних обставин. Низька гнучкість більшості суб'єктів господарювання за таких умов фрункціонування проявляється у відносній повільності зміни процесів управління їх маркетинговою діяльністю. Водночас фокусом їх діяльності та ключовою цінністю залишається задоволення потреб цільових споживачів, що передбачає вивчення їх поведінки та управління системоутворюючими чинниками її формування в контексті реалізації стратегії підприємства.

Сучасним трендом наукових досліджень $€$ розвиток галузі поведінкової економіки, представник якої, професор Чиказького університету Річард Талер, отримав Нобелівську премію з економіки у жовтні 2017 р. Дослідження Річарда Талера безпосередньо пов'язані 3 економічною поведінкою споживача і обґрунтуванням впливу психологічних чинників на процес прийняття відповідного рішення про купівлю. При цьому автор вивчає вплив когнітивних чинників споживацької поведінки на формування системи економічної політики суб'єкта господарювання в умовах невизначеності зовнішнього маркетингового середовища. Фундатором поведінкової економіки нині вважається Даніель Канеман, який також отримав Нобелівську премію за власні наукові дослідження у 2002 р. Д. Канеман і В. Сміт зробили значний вклад у дослідження теорії «підштовхування» індивідуумів, згідно якої в своїй поведінці споживачі керуються окремими знаками та символами, що спонукають їх до прийняття тих чи інших рішень на ринку.

Враховуючи значний науковий доробок у теорії розвитку споживчої поведінки, варто зазначити, що у фрокусі сучасних досліджень знаходяться питання теоретико-методологічного обґрунтування категоріального апарату, 
умов та чинників фрормування поведінки споживача. Так, вітчизняні науковці О. Давидова, М. Солнцев, О. Зозульов акцентують увагу у своїх наукових дослідженнях на проблемах самоідентифрікації та самосприйняття сучасного індивідуума в контексті їх споживацької поведінки [2]. Такі дослідження $€$ особливо актуальними в процесі розробки маркетингової стратегії, сегментації та позиціювання товарів на ринку, обґрунтування цінності товарної пропозиції та бренд-буку, формування комунікаційної політики суб'єкта господарювання.

З позиції споживацької поведінки О. Зозульовим пропонується алгоритм фрормування унікальної торгової пропозиції (Unique Selling Proposition) на ринку В2B, що фокусується на відповідній цінності для цільового споживача [4]. Споживач як на промисловому, так і на споживчому ринку, здійснює процес купівлі під впливом зовнішніх та внутрішніх маркетингових чинників. Відтак, конкурентні позиції товаровиробника на ринку безпосередньо визначатимуться лояльністю цільового споживача та релевантністю його споживацької поведінки комунікаційній політиці підприємства.

К. Полторак досліджує поведінку споживачів в контексті розвитку Інтернету й соціальних мереж [7]. Враховуючи сучасний рівень технологічного розвитку економіки автор розглядає соціальні мережі не лише як провідний комунікаційний канал, а як повноцінний складний інформаційний простір, що доцільно використовувати всім суб'єктам господарювання на ринку. На підставі розробленої авторської моделі купівельної поведінки виділяються чинники впливу на споживацьку поведінку в мережі Інтернет, що безпосередньо впливають на процес здійснення купівлі як онлайн, так і офрлайн.

Важливим аспектом дослідження споживацької поведінки є її взаємозв'язок із забезпеченням економічної безпеки підприємства. Обґрунтування впливу чинників зовнішнього середовища на мотиваційні риси поведінки споживача представляється ключовими елементами реалізації політики економічної безпеки підприємства в довгостроковій перспективі [9]. При цьому споживацька поведінка представляється провідною складовою інформаційного забезпечення підприємства, що фрормується зовнішнім маркетинговим середовищем, і, відтак, є підґрунтям формування споживчої поведінки суб'єкта господарювання. В свою чергу, фрормування та реалізація стратегії підприємства безпосередньо визначається і корегується змінами його спо- живчої поведінки з метою забезпечення економічної, фрінансової, конкурентної і технологічної стійкості на ринку.

Ключовою характеристикою поведінки споживачів на ринку в контексті даного дослідження представляється ії класифрікація за різними типами. Так, поведінка сучасного споживача детермінується не тільки впливом зовнішніх чинників, а також і такими соціально-психологічними характеристиками, як світогляд, виховання, індивідуальні смаки й вподобання. 3 огляду на умови здійснення купівельних операцій покупців доцільно класиорікувати на відносно однорідні групи:

- гедоністи - цю групу споживачів особи, що розглядають процес здійснення купівлі та споживання як специфічне задоволення, наслідують модні тренди, підтримують статусність як окремий стандарт споживання, очевидно, що такий тип споживання реалізується у купівельну поведінку за відповідного рівня платоспроможності;

- раціоналісти - цю групу фрормують споживачі, купівельна поведінка яких ґрунтується на прийнятті зважених рішень, що приймаються на основі вивчення ринку через призму критичного сприйняття рекламної інформації, що позначається на низькому рівні здійснення імпульсивних купівель;

- консерватори - до цієї групи належать особи, що звужують споживання до базового набору продуктів, що спричинено комплексом причин: від економічних до індивідуальнопсихологічних.

В цілому на поведінку споживачів впливають чинники як екзогенного (соціальнополітичні, економічні, екологічні, культурнорелігійні тощо), так і ендогенного характеру (світогляд, система цінностей, індивідуальні смаки й вподобання тощо), при цьому за способом впливу екзогенні фрактори, як правило, інтронізуються у алгоритм здійснення купівельної поведінки індивіда через ендогенні прямо або опосередковано.

Модель управління купівельною поведінкою фрундаментально детермінується структурою та типом ринку, оскільки технологія впливу на процес прийняття рішення про купівлю та післяпродажну підтримку комунікації із цільовою аудиторією суттєво відрізняється на В2С та В2В ринках, зокрема, на промислових ринках доцільно вирізняти підприємства-виробники, підприємства-посередники, державні та некомерційні установи й організації з огляду на диореренціацію мотиваційної, комунікативної та логістичної скла- 
дових механізму реалізації купівельної поведінки різних типів контрагентів та клієнтів.

В основі сучасних багатовекторних наукових досліджень в сорері маркетингу лежить ключове розуміння поведінки споживачів, що дає відповіді на ключові питання теорії прийняття рішень про купівлю. Знання закономірностей імплементації алгоритму споживацької поведінки та їх застосування у бізнес-технологіях підприємства значно підвищує ефрективність маркетингових кампаній. Базовими теоріями споживацької поведінки розглядаються модель Engel-Kollat-Blackwell (EKB), теорія потреб, теорія імпульсивної купівлі. Теорії споживчої поведінки пояснюють актуальні фееномени, зокрема, індивідуальні та групові купівлі, роль емоцій у прийнятті та верифрікації рішень про покупку, процес фрормування лояльності тощо.

Модель ЕКВ описує поетапний процес здійснення купівлі, що передбачає отримання споживачем інорормації щодо ринкової продуктової пропозиції та іiї параметрів; обробку отриманої інсрормації та порівняння iї 3 минулим досвід, а також очікуваннями; раціональне усвідомлення оптимального вибору. Модель ЕКВ демонструє екстремуми маркетингового впливу в процесі прийняття рішення про купівлю споживачами: на початковому етапі «поглинання» інформації маркетологи повинні надавати споживачам вичерпну інорормацію про продукт, щоб спонукати споживача зберегти ваш продукт в списку можливих варіантів перед ухваленням рішення про покупку; на етапі побудови активної комунікації підприємства з цільовою аудиторією 3 метою дисреренціації бренду на основі демонстрації унікальної цінності та ідентичності бренду.

Теорія потреб А. Маслоу дозволяє адаптувати маркетингові комунікації зі споживачами відповідно до структури потреб цільової аудиторії з огляду на пріоритетність покупки в ієрархії потреб. Теорія імпульсивної купівлі $\mathrm{X}$. Штерна компаративно обґрунтовує особливості раптових покупок відносно попередньо сорормованих раціональних рішень про покупку, зокрема, класифрікує категорії імпульсних покупок (чисто імпульсні покупки, маніпулятивні імпульсні покупки, імпульсні покупки, що здійснюються за наявності додаткового імпульсу, імпульсні рішення, засновані на підсвідомому раціональному вирішенні), а також визначає широкий діапазон маркетингових можливостей фрормування конкурентоспроможності, оскільки кожен продуктовий пара- метр, від упаковки до розміщення в магазині, впливає на імпульсний поштовх до купівлі.

Теорії поведінки споживачів передбачають аналітичну складову ідентифрікації алгоритму купівельної поведінки споживачів, що базується на концепції «7 O's» і складається з вивчення вхідної інфрормації щодо забезпечення ключових сракторів успіху на цільовому ринку:

- учасників ринку (хто здійснює покупки на ринку?);

- об'єктів процесу купівлі (які групи товарів реалізуються на цільових ринках, які релевантні групи потреб наразі актуальні і потребують задоволення певними товарними пропозиціями?);

- мотиваційно-цільовий механізм (для чого споживачі купують певні товари?);

- конкурентний профіль цільової аудиторії (які учасники ринку здійснюють впливи на цільових покупців);

- операційних процесів ринку (яким чином відбувається процес купівлі?);

- можливостей купівлі (коли здійснюється процес купівлі?);

- місця (каналів) збуту (де відбувається процес купівлі?).

Парадигма клієнтоорієнтованості бізнесу як ключової детермінанти конкурентоспроможності вимагає глибинного аналітичного обґрунтування механізму купівельної поведінки типового споживача. Управління клієнтським досвідом як бізнес-стратегія передбачає вибудовування безперервного процесу взаємин 3 клієнтом у різних точках контакту, що вимагає розробки релевантної моделі (таблиця 1).

Отже, на підставі аналізу сучасних теоретико-методологічних підходів щодо формування поведінки споживачів на ринках В2С та В2В доцільним вбачається окреслення інтегрованого концепту моделювання споживацької поведінки в контексті фрормування лояльності цільової аудиторії. Представляється, що, споживацька поведінка є фрормою взаємодії індивідууму із зовнішнім маркетингових середовищем та проявом його світосприйняття $з$ огляду на ментальні, культурні, психологічні та економічні характеристики. Використовуючи представлений механізм моделювання поведінки споживача суб'єкт господарювання має змогу розробляти та імплементувати інструментарій, що дозволяє аналізувати товарну пропозицію відносно структури потреб цільових споживачів, адаптувати товарний портсрель відносно 
Таблиця 1

\section{Структурна модель управління споживацькою поведінкою клієнтоорієнтованої компанії}

\begin{tabular}{|c|c|c|}
\hline Чинник & Реакція підприємства & Дії споживача \\
\hline Дослідження & $\begin{array}{l}\text { Обґрунтування методологічних } \\
\text { засад дослідження } \\
\text { Організація та здійснення } \\
\text { досліджень } \\
\text { Аналіз результатів досліджень } \\
\text { та обґрунтування пропозицій }\end{array}$ & $\begin{array}{l}\text { Участь в дослідженнях } \\
\text { Надання релевантної інорормації }\end{array}$ \\
\hline $\begin{array}{l}\text { Швидкість прийняття } \\
\text { рішення }\end{array}$ & Швидке реагування на ринку & \begin{tabular}{|l|} 
Швидкість процесу здійснення \\
покупки та споживання продукту
\end{tabular} \\
\hline Ресурси & $\begin{array}{l}\text { Залученість до процесу: фрінанси, } \\
\text { персонал тощо } \\
\text { Витрати: вплив на ціноутворення }\end{array}$ & $\begin{array}{l}\text { Вартість продукту: гроші, час, } \\
\text { увага, енергія, емоції }\end{array}$ \\
\hline Роздрібна торгівля & $\begin{array}{l}\text { Типи посередників } \\
\text { Збутова логістика } \\
\text { Мерчандайзинг }\end{array}$ & $\begin{array}{l}\text { Очікування відносно місця } \\
\text { покупки }\end{array}$ \\
\hline Надійність & $\begin{array}{l}\text { Контрольованість продуктових } \\
\text { ланцюгів }\end{array}$ & $\begin{array}{l}\text { Якість і постійна наявність товарів } \\
\text { Надійність роздрібного продавця } \\
\text { Можливість фрідбеку }\end{array}$ \\
\hline Лояльність & $\begin{array}{l}\text { Програми винагород для } \\
\text { постійних та лояльних клієнтів }\end{array}$ & $\begin{array}{l}\text { Соціальний та споживчий статус } \\
\text { продукту }\end{array}$ \\
\hline Взаємовідносини & $\begin{array}{l}\text { Персоніфрікація взаємовідносин із } \\
\text { учасниками продуктового ланцюга }\end{array}$ & $\begin{array}{l}\text { Почуття власної цінності } \\
\text { й індивідуальності } \\
\text { Задоволеність споживачів } \\
\end{array}$ \\
\hline Асортимент & Диореренційований маркетинг & Ідентифрікація пропозиції \\
\hline $\begin{array}{l}\text { Спеціальні акційні } \\
\text { пропозиції }\end{array}$ & $\begin{array}{l}\text { Формування пропозиції } \\
\text { за допомогою СRM-системи } \\
\text { на основі історії купівель }\end{array}$ & $\begin{array}{l}\text { Вибір релевантних офрерів } \\
\text { за змістом та інтерфейсом }\end{array}$ \\
\hline
\end{tabular}

Джерело: розроблено авторами

кон'юнктури ринку за кількісними та якісними параметрами, модернізувати комунікативні технології щодо споживачів та контактних аудиторій з метою забезпечення ефективності управління купівельною поведінкою цільових споживачів в контексті реалізації загальнокорпоративної стратегії підприємства.

Висновки. Таким чином, споживацька поведінка представляється визначальним чинником впливу на процес фрормування конкурентоспроможності підприємства в умовах насиченості ринків товарів та послуг. 3 огляду на те, що лояльність цільового споживача $€$ чинником актуальності суб'єкта господарювання на ринку, її забезпечення вважається пріоритетом розвитку підприємства в довгостроковій перспективі. Представлене дослідження визначає сукупність можливостей підприємства щодо моделювання поведінки цільового споживача та реалізації ії результатів на практиці, зокрема:

- ідентифрікація відповідності потреб споживачів і товарної асортиментної пропозиції, а також розробка стратегічної карти її модернізації чи модифрікації;
- фрормування дієвих каналів комунікації 3 цільовими аудиторіями щодо товарів 3 метою управління інорормаційними потоками, що детермінують прийняття рішення про купівлю з використанням системи мотивації;

- зміцнення впевненості споживача у правильності вибору на ринку;

- забезпечення фрідбеку щодо ступеня задоволеності потреб цільової аудиторії як основи для управління товарним асортиментом.

Методологічні основи вивчення поведінки споживача традиційно кваліфрікуються у системі координат загальнонаукових аналітикопрогностичних методик досліджень, компліментарних іншим сорерам знань. Переважно такі методики дослідження передбачають використання комплексного підходу, економіко-статистичних методів, програмного планування та програмування, економікоматематичного моделювання, експертизи, ділових ігор, відповідних методичних інструментів сорер соціології, психології, екології та дизайну. Найбільш актуальними в сучасній практиці маркетингових досліджень є такі способи отримання та аналізу первинної 
інорормації, як спостереження, експеримент і опитування. При цьому кількісний вимір індивідуальних смаків, емоцій або настроїв споживачів передбачає застосування специорічних, в т. ч. й експертних, методів. В цьому контексті перспективами подальших досліджень вбачається пошук стратегічно орієнтованих методичних підходів щодо застосування результатів дослідження та моделювання поведінки споживача як однієї з ключових теоретичних та прикладних проблем маркетингу.

\section{СПИСОК ВИКОРИСТАНИХ ДЖЕРЕЛ:}

1. Блэкуэлл Р., Миниард П., Энджел Дж. Поведение потребителей : учебник. Санкт-Петербург, 2007. 944 с.

2. Давидова О.Б., Солнцев М.І., Зозульов О.В. Споживач у сучасному світі: проблеми ідентисрікації, самосприйняття і взаємовідносини з навколишнім світом. Використання в маркетингу. Актуальні проблеми економіки та управління. № 12. 2018. URL: file:///C:/Users/\%D0\%9D\%D0\%B0\%D1\%82\%D0\%B0\%D0\%BB\%D0\%B8\% D1\%8F/Downloads/130983-280954-1-SM.pdf

3. Жовковська Т. Формування моделі поведінки споживача. Економічний дискурс. № 2. 2017. URL: http://ed.pdatu.edu.ua/article/view/126058/120746

4. Зозульов О.В., Василенко А.Т. Аналіз поведінки споживачів на промисловому ринку для формування торгової пропозиції. Економічний вісник Національного технічного університету України. № 14. 2017. URL: file:///C:/Users/\%D0\%9D\%D0\%B0\%D1\%82\%D0\%B0\%D0\%BB\%D0\%B8\%D1\%8F/Downloads/ evntukpi_2017_14_49.pdf

5. Котлер Ф., Вонг В., Сондерс Дж. Основы маркетинга : учебник. Москва, 2012. 752 с.

6. Полторак К.А. Аналіз особливостей поведінки споживачів в мережі Інтернет. Ефективна економіка. № 11. 2015. URL: http://www.economy.nayka.com.ua/pdf/11_2015/99.pdf

7. Прокопенко О.В., Троян М.Ю. Поведінка споживачів : навч. посібник. Київ, 2008. 176 с.

8. Раца О.Б. Стратегічне управління споживчою поведінкою підприємства у системі забезпечення економічної безпеки. Науковий вісник Херсонського державного університету. Серія «Економічні науки». № 23. 2017. URL: http://www.ej.kherson.ua/journal/economic_23/1/41.pdf

9. Семенда Д.К., Семенда О.В. Дослідження поведінки споживачів в сучасних ринкових умовах. Молодий вчений. № 1 (53). URL: http://molodyvcheny.in.ua/files/journal/2018/1/126.pdf

\section{REFERENCES:}

1. Blackwell R., Miniard P., Engel J. (2007). Customer Behavior. Saint Petersburg: Piter.

2. Davidova O., Solncev M., Zozulyov O. (2018). Customer is in the Consumer in the modern world: problems of identification, self-perception and relationships with the outside world. Use in marketing. Current problems of economics and management. Retrieved from: ///C:/Users/\%D0\%9D\%D0\%B0\%D1\%82\%D0\%B0\%D0\%BB\%D0\%B8\%D1\%8F/Downloads/130983-280954-1-SM.pdf

3. Zhovkovska T. (2017). Formation of a model of consumer behavior. Economic discourse. Retrieved from: http://ed.pdatu.edu.ua/article/view/126058/120746

4. Zozulyov O., Vasilenko A. (2018). Analysis of consumer behavior in the industrial market to form a trade offer. Economic Bulletin of the National Technical University of Ukraine. Retrieved from: IIIC:/Users/\%D0\%9D\%D0\%B0\%D1\%82\%D0\%B0\%D0\%BB\%D0\%B8\%D1\%8F/Downloads/evntukpi_2017_14_49.pdf

5. Kotler F., Vong V., Sonders J. (2012). Basics of marketing. Moscow: Williams.

6. Poltorak K. (2015). Analysis of consumer behavior on the Internet. Efficient economy. Retrieved from: http://www.economy.nayka.com.ua/pdf/11_2015/99.pdf

7. Prokopenko O., Troyan M. (2008). Customer Behavior: Kyiv: Center for Educational Literature.

8. Ratza O. (2017). Strategic management of consumer behavior of the enterprise in the system of economic security. Scientific Bulletin of Kherson State University. Economic Sciences Series. Retrieved from: http://www.ej.kherson.ua/journal/economic_23/1/41.pdf

9. Semenda D., Semenda O. (2018). Research of consumer behavior in modern market conditions. A young scientist. Retrieved from http://molodyvcheny.in.ua/files/journal/2018/1/126.pdf 